MACHINE BUILDING. PROCESS METALLURGY.

MATERIALS SCIENCE

МАШИНОБУДУВАННЯ. ТЕХНОЛОГІЯ МЕТАЛІВ.

МАТЕРІАЛОЗНАВСТВО

UDC 624.072.2

Yu.S. Krutiy, PhD, Prof.

Odessa State Academy of Civil Engineering and Architecture, 1 Koval'ska Str., 65029 Odessa, Ukraine; e-mail: marshall@te.net.ua

\title{
FORCED HARMONIC OSCILLATIONS OF THE EULER-BERNOULLI BEAM WITH RESISTANCE FORCES
}

\begin{abstract}
Ю.С. Крутій. Вимушені гармонічні коливання балки Ейлера-Бернуллі з урахуванням сил опору. Важливим питанням в теорії коливань $€$ вивчення впливу опорів на коливальні процеси. На відміну від розрахунків вільних коливань, дослідження коливань поблизу резонансу вимагає врахування сил опору. Особлива увага приділяється вимушеним поперечним коливанням балок, як важливій технічній проблемі для галузей машинобудування та будівництва. Мета: Метою роботи є побудова аналітичного рішення задачі про вимушені поперечні коливаннях прямого стрижня постійного поперечного перерізу, що знаходиться під впливом гармонійного навантаження, з урахуванням зовнішнього і внутрішнього опорів. Матеріали $\boldsymbol{i}$ методи: Внутрішній опір враховується за скоректованою гіпотезою Кельвіна-Фойгта, яка відображає підтверджений шляхом експерименту факт про частотнонезалежне внутрішнє тертя в матеріалі. Природа зовнішнього тертя також вважається частотно-незалежною. Результати: Побудовано аналітичний розв'язок диференціального рівняння вимушених поперечних коливань прямого стержня постійного перерізу, що перебуває під дією рівномірно розподіленого гармонічного навантаження, з урахуванням зовнішнього та внутрішнього опорів. Як наслідок, в аналітичному вигляді отримано формули, які дозволяють визначати вимушені динамічні коливання та динамічні внутрішні зусилля від гармонічного навантаження стержня, зводячи задачу при будь яких можливих закріпленнях кінців до пошуку невідомих сталих інтегрування, які представлено у формі початкових параметрів.

Ключові слова: балка Ейлера-Бернуллі, вимушені коливання, диференціальне рівняння, початкові параметри, точний розв'язок.

Yu.S. Krutiy. Forced harmonic oscillations of the Euler-Bernoulli beam with resistance forces. The important issue in the oscillation theory is the study of resistance impact on oscillatory processes. Unlike the calculations of free oscillations, that reside in determination of natural frequencies and waveshapes and unlike the calculations of forced oscillations far away from resonance, that are performing without reference to friction, the oscillations researches in vicinity of resonance need accounting of friction forces. Special attention is paid to forced transverse fluctuations in beams as an important technical problem for engineering and building. Aim: The aim of the work is constructing of analytical solution of the problem of forced transverse vibrations of a straight rod with constant cross-section, which is under the influence of the harmonic load taking into account external and internal resistances. Materials and Methods: The internal resistance is taken into account using the corrected hypothesis of Kelvin-Voigt which reflects the empirically proven fact about the frequency-independent internal friction in the material. The external friction is also considered as frequency-independent. Results: An analytical solution is built for the differential equation of forced transverse oscillations of a straight rod with constant cross-section which is under the influence of the harmonic load taking into account external and internal resistances. As a result, analytically derived formulae are presented which describe the forced dynamic oscillations and the dynamic internal forces due to the harmonic load applied to the rod thus reducing the problem with any possible fixed ends to the search of unknown integration constants represented in a form of initial parameters.

Keywords: Euler-Bernoulli beam, forced oscillations, differential equation, initial parameters, exact solution.
\end{abstract}

Introduction. The important issue in the oscillation theory is the study of resistance impact on oscillatory processes. Unlike the calculations of free oscillations, that reside in determination of natural frequencies and waveshapes and unlike the calculations of forced oscillations far away from resonance, that are performing without reference to friction, the oscillations researches in vicinity of resonance need accounting of friction forces.

DOI 10.15276/opu.3.47.2015.03

(C) 2015 The Authors. This is an open access article under the CC BY license (http://creativecommons.org/licenses/by/4.0/). 
The reasons of energy dispersion during material body oscillations can be both external and internal. The external reasons - environmental resistance, where material bodies are oscillated (air or liquid), slip surfaces friction in joints of different elements and supporting structures. Energy dispersion in material owing to its imperfect elasticity refers to internal reasons. An internal inelastic resistance has paramount importance among resistances that come out from elastic systems oscillations.

There are a lot of studies about the rod vibrations problems. Among them are the works by D. Bernoulli, L. Euler, J.W. Rayleigh A.N. Krylov, S.P. Tymoshenko, K. Gogenemzera, W. Prager, P. Pfeiffer, P.F. Papkovich, A.F. Smirnova, I.M. Rabinovich, M.I. Bezukhov, A.P. Filippova, E.S. Sorokin and others.

The relevance of this problem in our days is confirmed by the large number of modern publications among which we can highlight such works [1..16]. Special attention is paid to forced transverse fluctuations in beams as an important technical problem for engineering and building. The most common method for the determination of these oscillations is to present the superimposed loads and the dynamic characteristics of a non-damping functions [2, 3]. Ladislav Fryba [12] applies integral Fourier transform and integral Laplace-Carson transformation to solve the same problem. M. Abu-Hilal using a method of Green functions gives the precise method of determining of a dynamic deviation of a simple-span beam of Euler-Bernoulli [15].

The aim of the work is constructing of analytical solution of the problem of forced transverse vibrations of a straight rod with constant cross-section, which is under the influence of the harmonic load taking into account external and internal resistances.

Materials and Methods. Let superpose $x$-axis with the centroidal line of cross-sections of the rod and assume that its ends are at the points $x=0$ and $x=l$. The deflections down are considered as positive ones. The general scheme of oscillations shown in Fig. 1. The scheme of the forces acting during vibrations upon an element of a rod is presented in Fig. 2.

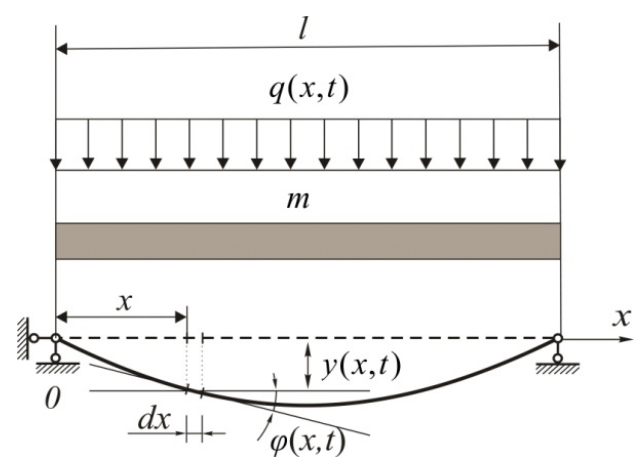

Fig. 1. The scheme of forced transverse vibrations of a straight rod

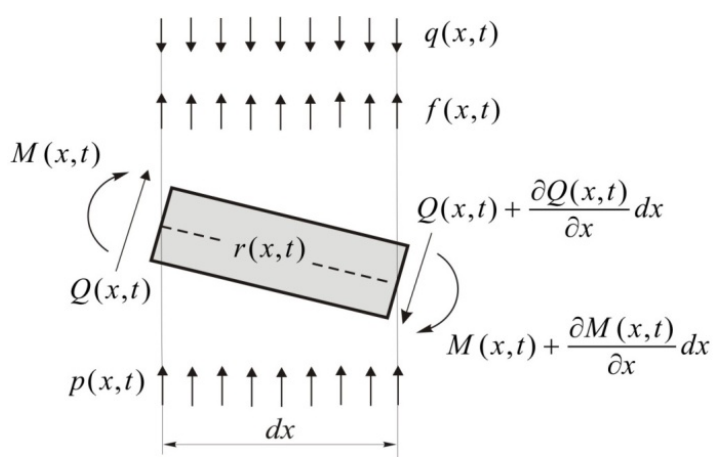

Fig. 2. The scheme of the forces acting upon an element of a rod

Here the following designations are accepted:

$q(x, t)$ - the intensity of dynamic transverse load acting upon the rod;

$m$ - the intensity of the distributed mass (bulk weight) of the rod;

$y(x, t)$ - the cross motion of the axis point of the rod with coordinate $x$ at time $t$ (dynamic deflection);

$\varphi(x, t)$ - the dynamic angular deflection;

$M(x, t)$ — the dynamic moment of flection;

$Q(x, t)$ - the dynamic transverse force;

$r(x, t)$ - the intensity of internal resistant forces;

$p(x, t)$ - the intensity of external motion resistance forces;

$f(x, t)=-m \frac{\partial^{2} y}{\partial t^{2}}-$ the intensity of inertial forces that appear during oscillation (D'Alembert force). 
It is known $[1,2]$ that the equation of forced oscillations considering resistances is written as:

$$
E I \frac{\partial^{4} y}{\partial x^{4}}+m \frac{\partial^{2} y}{\partial t^{2}}+p(x, t)+r(x, t)=q(x, t),
$$

where $E I$ - the lateral rigidity of a rod;

$E$ - the absolute value of the rod material elasticity;

$I$ - the second moment of rod cross-section area.

This equation is valid for a model where decided to ignore the longitudinal movement of cross sections and their twists and shifts.

Consider the important practical case when dynamic load acting on the rod outer is the harmonic one:

$$
q(x, t)=q \sin \theta t,
$$

where $q$ - the constant amplitude of transverse load, $\theta$ - the frequency of exciting force.

There are many hypotheses for accounting the resistance forces. For external friction, usually take the hypothesis that resistance is proportional to the mass of the rod and speed [2]. Internal friction is often considered on Kelvin-Voigt hypothesis [2]. According to this hypothesis, the strength of the internal resistance is proportional to the first order of strain rate. In this case, for the intensities of the resistance forces we will have:

$$
p(x, t)=\alpha m \frac{\partial y}{\partial t} ; \quad r(x, t)=\beta E I \frac{\partial^{5} y}{\partial t \partial x^{4}},
$$

where $\alpha, \beta-$ coefficients of external and internal friction accordingly.

However, as known, the Kelvin-Voigt hypothesis in pure form has a number of shortcomings. The main of it is that this hypothesis leads to conclusion that is contrary to experienced data. This conclusion is about frequency-dependent internal friction in the material. This disadvantage can be eliminated if to put the coefficient $\beta$ proportional to the frequency with which construction oscillates. In our case, we will have $\beta=\frac{\gamma}{\theta}$, where $\gamma$ - the coefficient of inelastic resistance (dimensionless constant for current material). The specified way of the accounting of internal friction is called the corrected Kelvin-Voigt hypothesis [1]. Applying for external forces version about frequency-independent friction, we obtain the representation $\alpha=v \theta$, where $v$ - the coefficient of inelastic resistance (dimensionless constant for current material).

The equation (1) taking into account (2), (3) takes form of

$$
E I \frac{\partial^{4} y}{\partial x^{4}}+m \frac{\partial^{2} y}{\partial t^{2}}+\alpha m \frac{\partial y}{\partial t}+\beta E I \frac{\partial^{5} y}{\partial t \partial x^{4}}=q \sin \theta t .
$$

We construct the exact solution of differential equation of oscillations in the partial derivatives (4) and obtain the formulas in analytical form for dynamic movements and dynamic internal forces in random cross-section of a rod.

We will search for equation (4) solution with generalized separation of variables of a type

$$
y(x, t)=y_{1}(x) \sin \theta t+y_{2}(x) \cos \theta t,
$$

where $y_{1}(x), y_{2}(x)$ - unknown real functions, that depends only on variable $x$. Then, for other dynamic parameters, we will have:

$$
\begin{aligned}
\varphi(x, t) & =\varphi_{1}(x) \sin \theta t+\varphi_{2}(x) \cos \theta t ; \\
M(x, t) & =M_{1}(x) \sin \theta t+M_{2}(x) \cos \theta t ; \\
Q(x, t) & =Q_{1}(x) \sin \theta t+Q_{2}(x) \cos \theta t,
\end{aligned}
$$

where

$$
\varphi_{j}(x)=y_{j}^{\prime}(x) ; M_{j}(x)=-E I \varphi_{j}^{\prime}(x) ; Q_{j}(x)=M_{j}^{\prime}(x) \quad(j=1,2) .
$$


Apparently, dynamic parameters of a beam will be completely defined by functions $y_{j}(x), \varphi_{j}(x), M_{j}(x), Q_{j}(x)(j=1,2)$. Let name them as components for corresponding dynamical parameters.

After the substitution of (5) to equation (4) we will obtain

$$
\begin{aligned}
& {\left[E I y_{1}^{I V}(x)-\theta^{2} m y_{1}(x)-\theta^{2} v m y_{2}(x)-\gamma E I y_{2}^{I V}(x)-q\right] \sin \theta t+} \\
& +\left[E I y_{2}^{I V}(x)-\theta^{2} m y_{2}(x)+\theta^{2} v m y_{1}(x)-\gamma E I y_{1}^{I V}(x)\right] \cos \theta t=0 .
\end{aligned}
$$

This equality have to satisfy itself for random $t$, that can be achieved only if to equate zero the multipliers at functions $\sin \theta t$ and $\cos \theta t$. As a result, we come to the system ordinary differential equations

$$
E I\left(\begin{array}{cc}
1 & -\gamma \\
\gamma & 1
\end{array}\right)\left(\begin{array}{l}
y_{1}^{I V}(x) \\
y_{2}^{I V}(x)
\end{array}\right)=\theta^{2} m\left(\begin{array}{cc}
1 & v \\
-v & 1
\end{array}\right)\left(\begin{array}{l}
y_{1}(x) \\
y_{2}(x)
\end{array}\right)+\left(\begin{array}{l}
q \\
0
\end{array}\right)
$$

The obtained system is equal to fourth order differential equation in relation to new unknown complex-valued function. Actually, the figuring in system matrixes reduced to diagonality by one and the same similarity transformation:

$$
S^{-1}\left(\begin{array}{cc}
1 & -\gamma \\
\gamma & 1
\end{array}\right) S=\left(\begin{array}{cc}
1+i \gamma & 0 \\
0 & 1-i \gamma
\end{array}\right) ; \quad S^{-1}\left(\begin{array}{cc}
1 & v \\
-v & 1
\end{array}\right) S=\left(\begin{array}{cc}
1-i v & 0 \\
0 & 1+i v
\end{array}\right)
$$

where $S=\left(\begin{array}{cc}1 & 1 \\ -i & i\end{array}\right)$

$i$ - the imaginary unit.

Consequently, after the substitution $\left(\begin{array}{l}y_{1}(x) \\ y_{2}(x)\end{array}\right)=S\left(\frac{z(x)}{z(x)}\right)$ the system (10) comes to the group of two differential equations in relation to new unknown functions

$$
z(x)=\frac{y_{1}(x)+i y_{2}(x)}{2}, \quad \overline{z(x)}=\frac{y_{1}(x)-i y_{2}(x)}{2} .
$$

The first of these equations has the form

$$
z^{I V}(x)-s^{4} z(x)=\frac{q}{2(1+i \gamma) E I},
$$

where $s^{4}=\frac{1-i \nu}{1+i \gamma} \theta^{2} \frac{m}{E I}$.

The second equation is the complex conjugation of the first one. Therefore, it is not necessary to consider it separately. Having the solution $z(x)$ for the first equation (12) the solution for the second will be $\overline{z(x)}$.

The functions of A.N. Krylov are usually chosen in the oscillation theory as a fundamental equation system of the form (12):

$$
\begin{array}{ll}
\Omega_{1}(s x)=\frac{1}{2}(\operatorname{ch} s x+\cos s x) ; & \Omega_{2}(s x)=\frac{1}{2}(\operatorname{sh} s x+\sin s x) ; \\
\Omega_{3}(s x)=\frac{1}{2}(\operatorname{ch} s x-\cos s x) ; & \Omega_{4}(s x)=\frac{1}{2}(\operatorname{sh} s x-\sin s x) .
\end{array}
$$

It is possible to obtain common formula by substituting here corresponding to them series instead of elementary functions

$$
\Omega_{n}(s x)=\frac{(s x)^{n-1}}{(n-1) !}+\sum_{k=1}^{\infty} \frac{(s x)^{4 k+n-1}}{(4 k+n-1) !} \quad(n=1,2,3,4) .
$$

An obvious partial solution of the equation (12) be

$$
z_{*}(x)=-\frac{q}{2 s^{4}(1+i \gamma) E I} .
$$


However, in this case it is more convenient to use fundamental functions

$$
X_{n}(x)=\frac{1}{(l s)^{n-1}} \Omega_{n}(s x) \quad(n=1,2,3,4)
$$

and particular solution

$$
z_{*}(x)=\frac{q l^{4}}{2(1+i \gamma) E I} X_{5}(x)
$$

where

$$
X_{5}(x)=\frac{1}{(l s)^{4}}\left[\Omega_{1}(s x)-1\right] .
$$

At the same time, with regard to formula (13), for $X_{n}(x)(n=1,2,3,4,5)$ we will have

$$
X_{n}(x)=\frac{1}{(n-1) !}\left(\frac{x}{l}\right)^{n-1}+\sum_{k=1}^{\infty} \frac{K^{2 k}}{(4 k+n-1) !}\left(\frac{x}{l}\right)^{4 k+n-1}(n=1,2,3,4,5),
$$

where $K^{2}=(s l)^{4}=\frac{1-i v}{1+i \gamma} l^{4} \theta^{2} \frac{m}{E I}$.

Let us remark here that $X_{5}(x)=\frac{1}{K^{2}}\left(X_{1}(x)-1\right)$.

Complex parameter $K$ is non-dimensional and it is easy to verify that by immediate examination. Then it is easy to see of formula (14) that the functions $X_{n}(x)(n=1,2,3,4,5)$ are nondimensional. In addition, these functions have the convenient rule of differentiation:

$$
X_{1}^{\prime}(x)=\frac{K^{2}}{l} X_{4}(x), X_{2}^{\prime}(x)=\frac{1}{l} X_{1}(x), X_{3}^{\prime}(x)=\frac{1}{l} X_{2}(x), X_{4}^{\prime}(x)=\frac{1}{l} X_{3}(x), X_{5}^{\prime}(x)=\frac{1}{l} X_{4}(x) .
$$

Writing out the common solution of the equation (12), we will have a complex function $y_{1}(x)+i y_{2}(x)$. Differentiating it taking into account (9) and (15), we will also obtain the complex functions $\varphi_{1}(x)+i \varphi_{2}(x), M_{1}(x)+i M_{2}(x), Q_{1}(x)+i Q_{2}(x)$. The final formulas, in which the integration constants are expressed through the initial complex parameters $y_{1}(0)+i y_{2}(0), \varphi_{1}(0)+i \varphi_{2}(0)$, $M_{1}(0)+i M_{2}(0), Q_{1}(0)+i Q_{2}(0)$, will have the form

$$
\begin{gathered}
y_{1}(x)+i y_{2}(x)=\left[y_{1}(0)+i y_{2}(0)\right] X_{1}(x)+\left[\varphi_{1}(0)+i \varphi_{2}(0)\right] l X_{2}(x)- \\
-\left[M_{1}(0)+i M_{2}(0)\right] \frac{l^{2}}{E I} X_{3}(x)-\left[Q_{1}(0)+i Q_{2}(0)\right] \frac{l^{3}}{E I} X_{4}(x)+\frac{q}{(1+i \gamma)} \frac{l^{4}}{E I} X_{5}(x) ; \\
\varphi_{1}(x)+i \varphi_{2}(x)=\left[y_{1}(0)+i y_{2}(0)\right] \frac{1}{l} K^{2} X_{4}(x)+\left[\varphi_{1}(0)+i \varphi_{2}(0)\right] X_{1}(x)- \\
-\left[M_{1}(0)+i M_{2}(0)\right] \frac{l}{E I} X_{2}(x)-\left[Q_{1}(0)+i Q_{2}(0)\right] \frac{l^{2}}{E I} X_{3}(x)+\frac{q}{(1+i \gamma)} \frac{l^{3}}{E I} X_{4}(x) ; \\
M_{1}(x)+i M_{2}(x)=-\left[y_{1}(0)+i y_{2}(0)\right] \frac{E I}{l^{2}} K^{2} X_{3}(x)-\left[\varphi_{1}(0)+i \varphi_{2}(0)\right] \frac{E I}{l} K^{2} X_{4}(x)+ \\
+\left[M_{1}(0)+i M_{2}(0)\right] X_{1}(x)+\left[Q_{1}(0)+i Q_{2}(0)\right] l X_{2}(x)-\frac{q}{(1+i \gamma)} l^{2} X_{3}(x) ; \\
Q_{1}(x)+i Q_{2}(x)=-\left[y_{1}(0)+i y_{2}(0)\right] \frac{E I}{l^{3}} K^{2} X_{2}(x)-\left[\varphi_{1}(0)+i \varphi_{2}(0)\right] \frac{E I}{l^{2}} K^{2} X_{3}(x)+ \\
+\left[M_{1}(0)+i M_{2}(0)\right] \frac{1}{l} K^{2} X_{4}(x)+\left[Q_{1}(0)+i Q_{2}(0)\right] X_{1}(x)-\frac{q}{(1+i \gamma)} l X_{2}(x) .
\end{gathered}
$$

Thus, complex functions which real part are the components $y_{1}(x), \varphi_{1}(x), M_{1}(x), Q_{1}(x)$ are found. In the role of the imaginary are the components $y_{2}(x), \varphi_{2}(x), M_{2}(x), Q_{2}(x)$. Conformably, in future it makes sense to distinguish real and imaginary components of dynamic parameters of (5)...(8). 
Let

$$
\begin{gathered}
X_{n}(x)=X_{n, 1}(x)-i X_{n, 2}(x)(n=1,2,3,4,5), \\
K^{2} X_{n}(x)=X_{n, 1}^{*}(x)-i X_{n, 2}^{*}(x)(n=1,2,3,4),
\end{gathered}
$$

where $X_{n, k}(x), X_{n, k}^{*}(x)(k=1,2)$ - real-valued functions, that have to be found.

For this case, let represent the number $K^{2}$ in trigonometric form. Based on the same (trigonometric) notation

$$
\begin{aligned}
& 1+i \nu=\sqrt{1+\nu^{2}}\left(\cos \delta_{1}+i \sin \delta_{1}\right), \quad \delta_{1}=\operatorname{arctg} \nu\left(0 \leq \delta_{1}<\frac{\pi}{2}\right), \\
& 1+i \gamma=\sqrt{1+\gamma^{2}}\left(\cos \delta_{2}+i \sin \delta_{2}\right), \quad \delta_{2}=\operatorname{arctg} \gamma\left(0 \leq \delta_{2}<\frac{\pi}{2}\right),
\end{aligned}
$$

we will have

$$
K^{2}=L^{2}(\cos \delta-i \sin \delta)
$$

where $L^{2}=\sqrt{\frac{1+v^{2}}{1+\gamma^{2}}} l^{4} \theta^{2} \frac{m}{E I}, \delta=\delta_{1}+\delta_{2}$.

After this the formula (14) taking the equality $K^{2 k}=L^{2 k}(\cos k \delta-i \sin k \delta)(k=1,2,3, \ldots)$ into account will be written in such way:

$$
X_{n}(x)=\frac{1}{(n-1) !}\left(\frac{x}{l}\right)^{n-1}+\sum_{k=1}^{\infty} \frac{L^{2 k} \cos k \delta}{(4 k+n-1) !}\left(\frac{x}{l}\right)^{4 k+n-1}-i \sum_{k=1}^{\infty} \frac{L^{2 k} \sin k \delta}{(4 k+n-1) !}\left(\frac{x}{l}\right)^{4 k+n-1} \quad(n=1,2,3,4,5) .
$$

Hence, also we will have

$$
K^{2} X_{n}(x)=\sum_{k=0}^{\infty} \frac{L^{2 k+2} \cos (k+1) \delta}{(4 k+n-1) !}\left(\frac{x}{l}\right)^{4 k+n-1}-i \sum_{k=0}^{\infty} \frac{L^{2 k+2} \sin (k+1) \delta}{(4 k+n-1) !}\left(\frac{x}{l}\right)^{4 k+n-1} \quad(n=1,2,3,4) .
$$

Therefore, the functions $X_{n, k}(x), X_{n, k}^{*}(x)(k=1,2)$ is found.

It is significant that $0 \leq \delta<\pi$, at that the equality $\delta=0$ is possible only if neither of resistance forces is not considered, i.e. $v=\gamma=0$.

Let now select and exclude real and imaginary summands in right part of equations (16)...(19). Then, for components $y_{k}(x), \varphi_{k}(x), M_{k}(x), Q_{k}(x)(k=1,2)$ we will have:

$$
\begin{aligned}
y_{k}(x)= & (-1)^{k+1}\left(y_{1}(0) X_{1, k}(x)+\varphi_{1}(0) l X_{2, k}(x)-\frac{M_{1}(0) l^{2}}{E I} X_{3, k}(x)-\frac{Q_{1}(0) l^{3}}{E I} X_{4, k}(x)\right)+ \\
+ & y_{2}(0) X_{1,3-k}(x)+\varphi_{2}(0) l X_{2,3-k}(x)-\frac{M_{2}(0) l^{2}}{E I} X_{3,3-k}(x)-\frac{Q_{2}(0) l^{3}}{E I} X_{4,3-k}(x)+ \\
& +(-1)^{k+1} \frac{q l^{4}}{\left(1+\gamma^{2}\right) E I}\left(X_{5, k}(x)+(-1)^{k} \gamma X_{5,3-k}(x)\right) ; \\
\varphi_{k}(x)= & (-1)^{k+1}\left(\frac{y_{1}(0)}{l} X_{4, k}^{*}(x)+\varphi_{1}(0) X_{1, k}(x)-\frac{M_{1}(0) l}{E I} X_{2, k}(x)-\frac{Q_{1}(0) l^{2}}{E I} X_{3, k}(x)\right)+ \\
+ & \frac{y_{2}(0)}{l} X_{4,3-k}^{*}(x)+\varphi_{2}(0) X_{1,3-k}(x)-\frac{M_{2}(0) l}{E I} X_{2,3-k}(x)-\frac{Q_{2}(0) l^{2}}{E I} X_{3,3-k}(x)+ \\
& +(-1)^{k+1} \frac{q l^{3}}{\left(1+\gamma^{2}\right) E I}\left(X_{4, k}(x)+(-1)^{k} \gamma X_{4,3-k}(x)\right) ;
\end{aligned}
$$




$$
\begin{aligned}
M_{k}(x)= & (-1)^{k}\left(\frac{y_{1}(0) E I}{l^{2}} X_{3, k}^{*}(x)+\frac{\varphi_{1}(0) E I}{l} X_{4, k}^{*}(x)-M_{1}(0) X_{1, k}(x)-Q_{1}(0) l X_{2, k}(x)\right)- \\
- & \frac{y_{2}(0) E I}{l^{2}} X_{3,3-k}^{*}(x)-\frac{\varphi_{2}(0) E I}{l} X_{4,3-k}^{*}(x)+M_{2}(0) X_{1,3-k}(x)+Q_{2}(0) l X_{2,3-k}(x)+ \\
& +(-1)^{k} \frac{q l^{2}}{1+\gamma^{2}}\left(X_{3, k}(x)+(-1)^{k} \gamma X_{3,3-k}(x)\right) ; \\
Q_{k}(x)= & (-1)^{k}\left(\frac{y_{1}(0) E I}{l^{3}} X_{2, k}^{*}(x)+\frac{\varphi_{1}(0) E I}{l^{2}} X_{3, k}^{*}(x)-\frac{M_{1}(0)}{l} X_{4, k}^{*}(x)-Q_{1}(0) X_{1, k}(x)\right)- \\
- & \frac{y_{2}(0) E I}{l^{3}} X_{2,3-k}^{*}(x)-\frac{\varphi_{2}(0) E I}{l^{2}} X_{3,3-k}^{*}(x)+\frac{M_{2}(0)}{l} X_{4,3-k}^{*}(x)+Q_{2}(0) X_{1,3-k}(x)+ \\
& +(-1)^{k} \frac{q l^{2}}{1+\gamma^{2}}\left(X_{2, k}(x)+(-1)^{k} \gamma X_{2,3-k}(x)\right) ;
\end{aligned}
$$

Results and Discussion. Thus, dynamic parameters of beam are completely defined by formulas (5)...(8), (22)...(25). The given expressions allow to define forced dynamic oscillations $y(x, t), \varphi(x, t)$ and dynamic internal forces $M(x, t), Q(x, t)$ from the harmonic load $q(x, t)=q \sin \theta t$. That reduces the problem with any possible fixed ends of the beam to the search for unknown constants of integration, which are represented in the formulas (22)...(25) in the form of real initial parameters (initial values of the real and imaginary components). There are two possible approaches. The first is based on implementation of boundary conditions using the formulas (22)...(25) and leads to a system of four linear inhomogeneous equations with four unknown real initial parameters. The second assumes the realization of boundary conditions using the formulas (16)...(19) and leads to a system of two inhomogeneous linear equations with two unknown complex initial parameters. After solving of such a system, separating the real and imaginary parts in the retrieved complex parameters, we obtain the four required real initial parameters. The second approach is more straightforward, because solution of a system of two equations is easy to obtain in an analytical form.

In practice, instead of the formulas (5) ... (8) for research of oscillations it is advisable to use the equipotent formulas where amplitude functions of their dynamic parameters are explicitly allocated:

$$
\begin{gathered}
y(x, t)=y(x) \sin \left(\theta t+\chi_{y}(x)\right), \quad y(x)=\sqrt{y_{1}^{2}(x)+y_{2}^{2}(x)}, \quad \chi_{y}(x)=\operatorname{arctg} \frac{y_{2}(x)}{y_{1}(x)} \\
\varphi(x, t)=\varphi(x) \sin \left(\theta t+\chi_{\varphi}(x)\right), \varphi(x)=\sqrt{\varphi_{1}^{2}(x)+\varphi_{2}^{2}(x)}, \chi_{\varphi}(x)=\operatorname{arctg} \frac{\varphi_{2}(x)}{\varphi_{1}(x)} \\
M(x, t)=M(x) \sin \left(\theta t+\chi_{M}(x)\right), \quad M(x)=\sqrt{M_{1}^{2}(x)+M_{2}^{2}(x)}, \chi_{M}(x)=\operatorname{arctg} \frac{M_{2}(x)}{M_{1}(x)} \\
Q(x, t)=Q(x) \sin \left(\theta t+\chi_{Q}(x)\right), Q(x)=\sqrt{Q_{1}^{2}(x)+Q_{2}^{2}(x)}, \chi_{Q}(x)=\operatorname{arctg} \frac{Q_{2}(x)}{Q_{1}(x)}
\end{gathered}
$$

\section{Література}

1. Василенко, М.В. Теорія коливань і стійкості руху / М.В. Василенко, О.М. Алексейчук. - К.: Вища школа, 2004. - 525 с.

2. Бабаков, И.М. Теория колебаний / И.М. Бабаков. - 4-е изд., испр. - М.: Дрофа, 2004. - 591 с.

3. Rao, S.S. Vibration of Continuous Systems / S.S. Rao. - Hoboken: John Wiley \& Sons, 2007. - 720 p.

4. Wang, C.Y. Structural Vibration: Exact Solutions for Strings, Membranes, Beams, and Plates / C.Y. Wang, C.M. Wang. - Boca Raton: CRC Press, 2014. - 293 p.

5. Exact frequency equations of free vibration of exponentially non-uniform functionally graded Timoshenko beams / A.-Y. Tang, J.-X. Wu, X.-F. Li, K.Y. Lee // International Journal of Mechanical Sciences. - 2014. - Vol. 89. - PP. $1-11$. 
6. Advances in Vibration Analysis Research / ed. by F. Ebrahimi. — Rijeka: In Tech, 2011. — 468 p.

7. Recent Advances in Vibrations Analysis / ed. by N. Baddour. — Rijeka: In Tech, 2011. — 248 p.

8. Rao, S.S. Mechanical Vibrations / S.S. Rao. $-5^{\text {th }}$ Edition. — Upper Saddle River: Prentice Hall, 2011. — $1084 \mathrm{p}$.

9. Sinha, A.K. Vibration of Mechanical Systems / A.K. Sinha. — New York: Cambridge University Press, 2010. - $308 \mathrm{p}$.

10. Balachandran, B. Vibrations / B. Balachandran, E.B. Magrab. $-2^{\text {nd }}$ Edition. - London: Cengage Learning, 2008. - 716 p.

11. Yavari, A. On nonuniform Euler-Bernoulli and Timoshenko beams with jump discontinuities: application of distribution theory / A. Yavari, S. Sarkani, J.N. Reddy // International Journal of Solids and Structures. - 2001. - Vol. 38, Issues 46-47. — PP. 8389 - 8406.

12. Fryba, L. Vibration of Solids and Structures under Moving Loads / L. Fryba. $-3{ }^{\text {rd }}$ Edition. — Prague: Academia, 1999. - $494 \mathrm{p}$.

13. Inman, D.J. Engineering Vibration / D.J. Inman. $-4^{\text {th }}$ Edition. - Boston: Pearson, 2014. -707 p.

14. Critical load for buckling of non-prismatic columns under self-weight and tip force / D.J. Wei, S.X. Yan, Z.P. Zhang, X.-F. Li // Mechanics Research Communications. — 2010. — Vol. 37, Issue 6. PP. $554-558$.

15. Abu-Hilal, M. Forced vibration of Euler-Bernoulli beams by means of dynamic Green functions / M. Abu-Hilal // Journal of Sound and Vibration. — 2003. — Vol. 267, Issue 2. — PP. 191 - 207.

\section{References}

1. Vasilenko, M.V., \& Aleksiichuk, O.M. (2004). Theory of Vibrations and Dynamic Stability. Kyiv: Vyshcha Shkola.

2. Babakov, I.M. (2004). Theory of Vibrations ( $4^{\text {th }}$ Ed.). Moscow: Drofa.

3. Rao, S.S. (2007). Vibration of Continuous Systems. Hoboken: John Wiley \& Sons. DOI: $10.1002 / 9780470117866$

4. Wang, C.Y., \& Wang, C.M. (2014). Structural Vibration: Exact Solutions for Strings, Membranes, Beams, and Plates. Boca Raton: CRC Press.

5. Tang, A.-Y., Wu, J.-X., Li, X.-F., \& Lee, K.Y. (2014). Exact frequency equations of free vibration of exponentially non-uniform functionally graded Timoshenko beams. International Journal of Mechanical Sciences, 89, 1-11. DOI:10.1016/j.ijmecsci.2014.08.017

6. Ebrahimi, F. (Ed.). (2011). Advances in Vibration Analysis Research. Rijeka: In Tech. DOI: $10.5772 / 639$

7. Baddour, N. (Ed.). (2011). Recent Advances in Vibrations Analysis. Rijeka: In Tech. DOI:10.5772/861

8. Rao, S.S. (2011). Mechanical Vibrations $\left(5^{\text {th }}\right.$ Ed.). Upper Saddle River: Prentice Hall.

9. Sinha, A.K. (2010). Vibration of Mechanical Systems. New York: Cambridge University Press.

10. Balachandran, B., \& Magrab, E.B. (2008). Vibrations $\left(2^{\text {nd }}\right.$ Ed.). London: Cengage Learning.

11. Yavari, A., Sarkani, S., \& Reddy, J.N. (2001). On nonuniform Euler-Bernoulli and Timoshenko beams with jump discontinuities: application of distribution theory. International Journal of Solids and Structures, 38(46-47), 8389-8406. DOI:10.1016/S0020-7683(01)00095-6

12. Fryba, L. (1999). Vibration of Solids and Structures under Moving Loads ( $3^{\text {rd }}$ Ed.). Prague: Academia.

13. Inman, D.J. (2014). Engineering Vibration (4 ${ }^{\text {th }}$ Ed.). Boston: Pearson.

14. Wei, D.J., Yan, S.X., Zhang, Z.P., \& Li, X.-F. (2010). Critical load for buckling of non-prismatic columns under self-weight and tip force. Mechanics Research Communications, 37(6), 554-558. DOI:10.1016/j.mechrescom.2010.07.024

15. Abu-Hilal, M. (2003). Forced vibration of Euler-Bernoulli beams by means of dynamic Green functions. Journal of Sound and Vibration, 267(2), 191-207. DOI:10.1016/S0022-460X(03)00178-0 